\title{
SPATIAL STRUCTURE OF MELANISM IN YELLOW-BELLIED MARMOTS
}

\author{
GEORGE MONTOPOLI $\downarrow$ NICK VISSER $\downarrow$ MICHAEL CRONE \\ UNIVERSITY OF WYOMING $\downarrow$ LARAMIE
}

\begin{abstract}
$\downarrow \quad$ ABSTRACT
Melanism (black fur coloration) in the yellow-bellied marmot, Marmota flaviventris, is encountered uniquely in the Teton Range in northwest Wyoming. This study is designed to investigate whether the occurrence of melanism is associated with reduced predation due to high human activity. Because overuse by humans can particularly stress the environment, the implications of this project are especially significant for Grand Teton National Park where efforts are directed to minimizing human impact. In addition, an estimation technique to calculate the likelihood that the melanistic allele is dominant is developed.
\end{abstract}

\section{$\downarrow \quad$ INTRODUCTION}

The biology of melanism in the yellowbellied marmot Marmota flaviventris found in Grand Teton National Park (GTNP) may provide an informative model of rapid evolution in an environment altered by human activities. Melanism in the yellow-bellied marmot has been documented only in the Tetons (Fryxell 1928, Murie 1934, Armitage 1961), although it is fairly common in other sciurids (Kiltie 1989), and melanism has gone to fixation in the Vancouver marmot (Armitage, pers. comm., May 1994). Neither the functional significance of melanism, nor the factors that affect temporal and spatial variation in its expression, have been investigated.

In a series of classic papers, Kettlewell (1961), and Clarke and Sheppard

(1966)

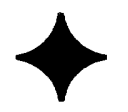

incidence of melanism in the peppered moth Biston bistularia could be explained in terms of differential vulnerability to avian predators in a changing environment. The normal light-colored phase of peppered moths was highly cryptic on tree bark, and melanistic phenotypes were rare in pre-industrial England. With the large amounts of particulate pollutants emitted by nineteenth century factories, the tree bark on which the moths usually rested became darker, so that normal-phased moths were no longer cryptic. Consequently, melanistic phenotypes enjoyed the protection conferred by crypticity, selection favored the melanistic allele, and most moths were melanistic by the 1930's. The peppered moth presents one of the clearest examples of short-term evolution in a free-ranging animal population, and of human influence on animal coevolution.

The yellow-bellied marmot in the Tetons may present another example of short-term evolution influenced by humans. This may be explained by considering the advantages and disadvantages afforded a species through natural selection in the presence of melanistic pelage. Melanistic pelage may be advantageous to the evolution of a species under specific environmental conditions. In a bioenergetics study, Kilgore (1972) showed that marmots stored more energy in net production than do populations of non-hibernating mammals, perhaps utilizing solar energy as a major component of the maintenance of body temperature, and thus conserving metabolic energy. In avian species, Walsberg et al. (1978) demonstrated conditions under which thermoregulatory advantages found in dark plumage favored the evolution of a species where predation was not a factor. Melanistic pelage 
in marmots could thus present thermoregulatory advantages vital to survival providing predation was not a factor.

On the other hand, the melanistic trait may be disadvantageous. Yellow-bellied marmots are subject to predation by birds, coyotes, and mustelids (Craighead, 1951; Travis and Armitage 1972; Armitage 1982). While three-fourths of their aboveground behavior is devoted to sunning and watching, less time is devoted to strictly watching (Travis and Armitage 1972; Montopoli \& Visser, pers. obs., 1994). Yellow-bellied marmots are consequently vulnerable to predation. The Teton terrain typically is light-colored, so that melanistic marmots are not cryptic, and likely are more easily seen by predators than their normal-pelaged conspecifics. A similar observation was made by $\mathrm{H}$. S. Swarth (1912) in the Marmota vancouverensis when he stated: "Their extreme weariness is correlated with conspicuousness, for the dark brown pelage shows in marked contrast against either gray rocks or green grass."

However, in the presence of humans, especially high densities of backcountry hikers and climbers, predation on melanistic marmots may be reduced because of the disturbance presented to predators. If predators, especially avian ones, are more affected by human disturbance than marmots, then predation on marmots near areas of high human use could be lower than elsewhere, allowing the melanistic phenotype to be more common since it would be "selected for" due to the thermoregulatory advantages. This variation in predation rates should result in higher rates of melanism near greater concentrations of humans. A high incidence of melanism may be correlated to use (or overuse) by humans.

\section{SHORT-TERM OBJECTIVES OF THIS STUDY ARE TO:}

1. establish censusing procedures;

2. define age and color groups;

3. determine the extent of human use in the Teton Range; and

4. determine the extent of melanism in the Teton Range.

\section{MAJOR, LONG-TERM OBJECTIVES OF THIS} STUDY ARE TO:

1. Document geographic variation in the incidence of melanistic phenotype, especially relative to the intensity of human use. The null hypothesis in this phase is:

$\mathrm{H}_{0}$ : Marmots near areas of high human use exhibit the same rates of melanism in areas of low human use.

2. Measure differential survival of melanistic and non-melanistic phenotypes, by comparing the incidence of fur coloration among age classes (juveniles, yearlings/subadults, and adults). The null hypothesis in this phase is:

$\mathrm{H}_{0}$ : Melanistic marmots have the same survival rates among age groups as non-melanistic marmots.

\section{RESEARCH DESIGN}

\section{SURVEY TECHNIQUE}

To test these hypotheses, transects were established to estimate geographic variation in the incidence of melanism. The transects were initially located perpendicular to trails, and consisted of three $50 \mathrm{~m}$ circular regions. One circular region was centered on the trail, and the other 2 circular regions were located with their centers $300 \mathrm{~m}$ from the trail, on opposite sides. This layout was based upon studies of marmot colonies and social behavior (Armitage 1962; 1974), and was designed to ensure that no overlap occurred between marmot colonies, so that individual marmots were not counted more than once during a single survey. Initial starting points were chosen randomly, and twenty minutes of observational time were apportioned to each circular region. An example of the transect layout in Cascade Canyon is demonstrated in Figure 1. 


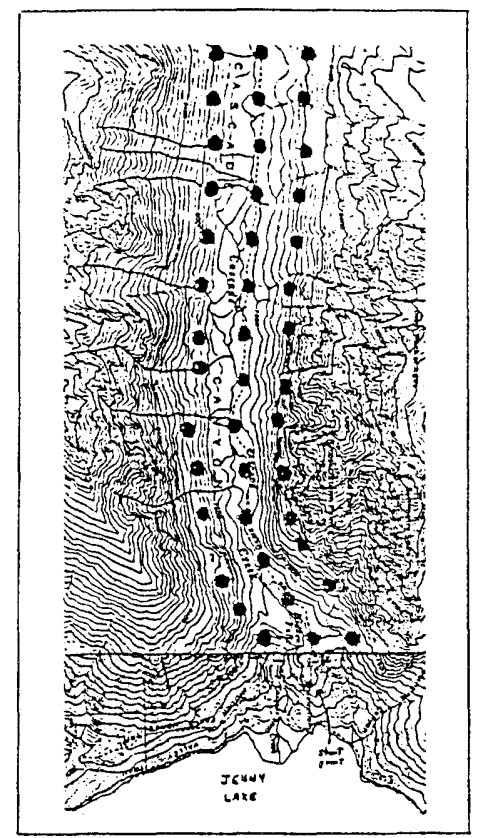

Figure 1. Original Layout of Transects to Investigate Melanism in Yellow-Bellied marmots, Cascade Canyon, Grand Teton National Park, Wyoming (Scale: $4 \mathrm{~cm}=1 \mathrm{~km}$ ).

The actual surveying technique that was employed was modified from the transect method described above, because mountainous terrain in GTNP made this originally-proposed method impractical and often impossible. For example, many survey points inevitably fell on canyon walls, over cliff faces, or were difficult to reach because of water, vegetation, and terrain. Some survey points offered little view of the surrounding area or were not located in prime habitat areas (often due to terrain and vegetation), and consequently data collection was extremely limited. Finally, marmot observations were disproportionately greater near trails, and marmots were rarely encountered $300 \mathrm{~m}$ from the trail. This was perhaps due to: 1) marmots near trails have habituated to humans, while those distant from trails have not, and tend to hide; or 2) marmot populations are much more abundant near trails due to reduced-predation pressures and habituation to humans by the marmots (avian predators avoid humans, and mammalian predators habituating to humans are forcefully removed from the environment by park officials).

Initial tests of the transect survey method illustrated these and other problems. A more practical and efficient survey technique, which employed an irregular survey grid, was devised. Survey points were chosen in likely habitat areas identified by the field researchers on the basis of their potential to provide useful data. This often left large sections of a major survey area untouched, but made field research more efficient (increased number of sightings). Habitat areas (as interpreted by field researchers) formed geographical subsets of the major survey areas. The survey technique was adapted to each different geographical location (habitat area). Two types of survey techniques were applied: stationary and moving.

The majority of habitat areas were surveyed using the stationary technique. Habitat areas were "covered" by several fixed survey points, from which the field observer gathered data. These survey points were chosen to offer a maximum view of the area and minimize the impact from the observer's presence. In general, large boulders and ledges above an area offered the best view with minimum impact on marmot activity.

The original survey method called for observations to be made for half-hour periods from each survey point on the regular grid. However, upon entering a habitat area, the researcher often disturbed the marmots for 20 to 30 minutes with the degree of alarm often dependent on the proximity of the researcher. A survey time of one hour was consequently chosen because marmot numbers and activities were more accurately observed in the onehour period, despite the inevitable influence of the observer's presence. Furthermore, a one-hour stationary survey allowed the researcher to turn periodically and look in different directions to maximize the amount of data gathered from each point.

Geographic considerations in some habitat areas made the stationary technique very inefficient. For example, some habitat areas occurred in rolling terrain, mixed terrain, or forested areas. Application of the stationary method to such areas required a large number of survey points, each covering an area too small to justify a full one-hour survey. Thus, a moving survey technique was devised. The moving survey method involved slowly moving through an area and stopping for 15 to 30 minutes at points which offered a good view or a number of observations. This method allowed reasonably efficient data collection in such areas. 
The habitat areas selected by the field researcher excluded from the study some parts of the major survey areas. However, habitat areas and survey points were chosen to provide a maximum amount of useful data and cover a variety of survey areas in GTNP. Rigorous application of the originally-proposed transect method would have limited the survey because all the survey areas would not have been covered by the researcher. The selective method allowed all the major survey areas to be covered to some extent. Furthermore, habitat areas were selected with various degrees of human use. Thus, the data still allowed for the investigation of the relationship between pelage type and human use in the park.

Locations that were surveyed included Granite Canyon, Death Canyon, Alaska Basin, Avalanche Canyon, Garnet Canyon, Surprise/Amphitheater/Delta Lakes, Cascade Canyon (Lower, North and South Forks), Hanging Canyon, Paintbrush Canyon, Grizzly Bear Lake area, Taggart Lake burn area, Beaver Creek Boneyard, Climber's Ranch and Highland's Residential Area.

\section{MEASUREMENTS}

Approximately 500 marmot observations were recorded, from which 452 detailed marmot observations were used in the analysis (some observations only indicated locations of melanistic individuals for future investigation, and were not used in the analysis). Data collection occurred primarily in the morning and late afternoon (roughly 7-11am and $3-7 \mathrm{pm})$, since marmot activity was highest at these times. The mid-day was often spent evaluating potential habitat areas and surveying strategies.

Marmots were classified by pelage type into 3 categories (melanistic, normal, other), and by age into 3 categories (juveniles, yearlings/subadults, adults). They were also classified by behavior according to the following categories: distance from a burrow $(<5 \mathrm{~m},>5 \mathrm{~m})$, accompanied by young $(\mathrm{Y} / \mathrm{N})$, accompanied by others of same size (number), activity (foraging, sunning, nursing, grooming, watching, nest building, other), and social interaction (communication, play, aggressive, submissive, avoidance, none, other).
A substantial amount of variation was observed for pelage type. The categories originally defined for melanistic and normal-phased pelages were not clearly divided. For example, melanistic marmots were observed with gray or brown on some parts of their body (head and tail especially), and normal-phased marmots were observed with coloration varying from gray to light brown/gold to dark brown (almost melanistic). Thus, for purposes of analysis, three classifications were defined for pelage type:

1. melanistic pelage - animals that appeared entirely black except for white or tan patches on the face (Armitage 1961); 2. normal pelage - yellowish-brown animals with yellow bellies, with white between the eyes (Burt \& Grossenheider, 1976);

3 . other pelage - any color variation that could not be classified as melanistic or normal, such as hoary, gray, or incomplete black.

Because of difficulty in differentiating yearlings and subadults, 3 age categories were defined: juveniles, yearlings/subadults, and adults.

Generally, juveniles and adults were easily classified, especially during the early summer months.

\section{GENETIC ANALYSIS}

To better understand population dynamics and dispersion of the melanistic trait in the population, the dominant/recessive nature of pelagecolor alleles in yellow-bellied marmots was investigated. By employing the Hardy-Weinberg principle, the proportion of melanistic genes in the gene pool for populations was estimated from observations with the assumption that melanistic alleles were dominant. Then, by recording the number of normal-pelaged mothers with the number of melanistic juveniles, a model was formulated using conditional probability distribution theory. Model parameters were examined to see if their estimates agreed with those initially formulated under the Hardy-Weinberg principle. A similar formulation was constructed under the assumption that melanistic genes were recessive. The results under both assumptions were compared, to establish the likelihood that the gene for melanism was either dominant or recessive. 


\section{RESULTS AND DISCUSSION}

The following results and discussion pertain to this preliminary study in which the counting and surveying techniques previously discussed (shortterm goals) were established, and tested in the field. Although the major hypotheses of the study are addressed and results from the statistical analyses are summarized below, the results are questionable and further analyses from on-going studies are required to establish validity.

\section{MELANISM AND HUMAN USE}

Table 1 (see Appendix A) presents a detailed count of marmots surveyed in their respective areas during summer, 1994. Table 2 (see Appendix A) presents average daily backcountry-use information obtained from trail counters for the months of August, 1993, and July and August, 1994. This time period was selected because data were complete, and current backcountry-use demographics were represented. Table 3 (see Appendix A) presents the results of a backcountryuse survey answered by 13 backcountry rangers with extensive experience. The survey was based on a 1to-10 Likert scale (1 represented minimal human use; 10, maximum use), and was designed to measure relative use by humans in backcountry areas.

Information from Tables 1, 2, and 3 was compiled in an attempt to correlate geographic variation in the incidence of the melanistic phenotype with the intensity of human use. Tables 4 and 5 present data on the proportion of melanistic marmots in relation to human use scores and backcountry use respectively (see Appendix A) and represent information that was used in the correlation analysis.

The Spearman's rank correlation coefficient resulting from correlating the proportion of melanistic marmots with the Human Use Score (Table 4) was $0.141(\mathrm{P}=0.5728)$. The Pearson's correlation coefficient resulting from correlating the proportion of melanistic marmots with backcountry use (Table 5) was $0.193(\mathrm{P}=0.6186)$. Both analyses strongly indicated little correlation between the proportion of melanistic marmots and intensity of human use. Consequently, no further analyses will be performed on this part of the study.
Unfortunately, the surveying technique originally proposed did not provide appropriate data. The modified techniques as implemented also were inadequate, mainly due to the fact that most recorded observations of all phenotypes occurred in areas associated with humans (popular trails, lakes, etc.), and marmots were rarely encountered $300 \mathrm{~m}$ from these areas, or in other isolated areas where minimal time was spent. Therefore, based on this preliminary study, the effects of high human use of the environment on the increased incidence of melanism is presently inconclusive, and should be addressed in a long-term study over several years.

Future studies will be directed to gathering information using the modified survey technique in canyons of little human use (for example, Avalanche and Leigh Canyons) that are geographically similar to other areas of high human use. Approximately equal time will be spent in both areas, and the data from minimally-used areas will be compared to data from areas with high human use. Finally, the thermal environment surrounding melanistic and non-melanistic marmots will be investigated to see if black fur provides a thermal advantage in the moderately hostile thermal environment experienced in the Tetons.

\section{DIFFERENTIAL SURVIVAL OF MELANISTIC AND NON-MELANISTIC PHENOTYPES}

Differential survival rates of melanistic and non-melanistic phenotypes were examined by comparing the incidence of fur coloration among age classes. Figure 2 graphically depicts these proportions.

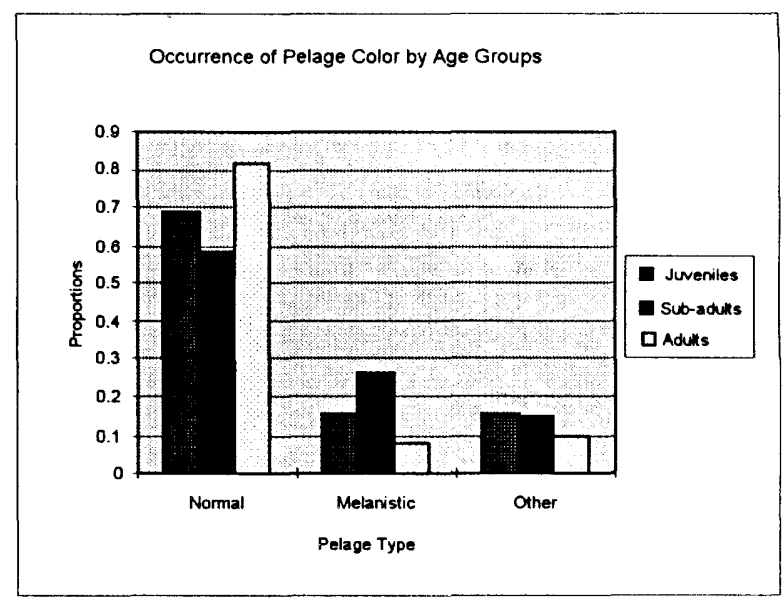

Figure 2. Differential survival rates of melanistic, nonmelanistic and other pheotypes. 
Table 6 (see Appendix A) presents frequencies and proportions of pelage color (normal, melanistic, other) by age groups (juveniles, yearlings/subadults, adults). A chi-square independence test was initially performed to determine if a significant difference in frequencies among each age category for different fur colorations existed. The test produced a chi-square value of $28.866(P=0.0000)$, indicating that differential survival rates were exhibited among age groups for a given fur coloration.

To examine which age groups within a specified fur coloration differed significantly, nine tests of pairwise differences of proportions were performed. The results are listed in Table 7 (see Appendix A).

At a level of significance of 0.05 , the proportion of adults with normal fur color significantly exceeded both yearlings/subadults with normal fur coloration $(P=0.0000)$, and juveniles with normal fur color $(P=0.0098)$. Given melanistic fur coloration, the proportion of yearling/subadults was significantly higher than both juveniles $(P=0.0416)$ and adults $(P=0.0000)$, while the proportion of juveniles exceeded that of adults $(P=0.0364)$. There was no significant difference among age groups given fur coloration that cannot be categorized as normal or melanistic (the "other" category).

Since several null hypotheses were tested in the same experiment (nine multiple comparisons were performed), a Bonferroni test was implemented to control experimentwise Type I error, in which an experimentwise level of significance of $0.05 / 9=$ 0.0056 was used (Woodward, Bonett, \& Brecht 1990). Using the experimentwise level of significance, the proportion of adults with normal fur color significantly exceeded the proportion of yearlings/subadults with normal fur coloration $(\mathrm{P}=$ 0.0000 ), and the proportion of melanistic yearling/subadults was significantly higher than the proportion of melanistic adults $(P=0.0000)$. In both the melanistic and normal fur pelages, significant differences occurred between yearling/subadult and adult age groups; however, more normal adults survived, while fewer melanistic adults survived.
One plausible explanation is that melanistic babies are more conspicuous to their mothers (and other marmots) and are afforded better protection within the colony during their first year(s) of development. After roughly one year, many yearlings/subadults disperse (Downhower and Armitage 1981) and no longer experience protection inherent to the colonial structure (for example, older marmots are producing new young). They may become more conspicuous and available to predators, and few reach adulthood. As stated previously, further analyses from on-going (longterm) studies are required to investigate this explanation and survivability among pelage types and age classes in general.

\section{GENETIC ANALYSIS}

Table 8 (see Appendix A) presents a listing of litter sizes and number of melanistic marmots in each litter by location. Based on these locations, the proportion of melanistic marmots in the corresponding populations where litters were observed was calculated to be 0.16955 .

\section{Case 1. Melanism Manifested by a Dominant Allele}

Under the assumption that melanism is manifested by a dominant allele at a single locus, and that only 2 alleles are responsible for fur coloration, application of the Hardy Weinberg Law yields:

$$
p=1-\sqrt{1-r}=0.0887,
$$

where $\mathrm{p}$ is the theoretical proportion of genes in the gene pool for melanism, and $r$ is the proportion of observed melanistic marmots.

Two methods were developed for examining the likelihood that melanism is manifested by a dominant allele. The first method is especially important when data are limited, and is based on the fact that if the mother is normal-phased and melanism is caused by a dominant allele, then she must have 2 non-melanistic alleles for fur coloration. Consequently, the juveniles other gene has $\mathbf{p}$ probability of being melanistic since there are $p$ genes in the gene pool for melanism. Therefore, if $\mathrm{s}$ represents the proportion of melanistic juveniles 
from non-melanistic mothers, then $s$ must equal $p$, and $s$ is calculated by:

$$
s=1-\sqrt{1-r}=0.0887 \text {, }
$$

From Table $8, s=10 / 46=0.2174$. The relative closeness of 0.2174 to 0.0887 , and the likelihood that melanism is manifested by a dominant allele, is evaluated later.

The second method, derived from conditional probability theory (conditioned on the mother being normal-phased), requires substantial data. By considering all possible paternal genotypes and assuming that the maternal genotype is homozygous recessive, probabilities associated with juvenile genotypes may be easily calculated using Punnett squares and the diagrams listed below:

\begin{tabular}{|c|c|c|c|c|c|}
\hline & & \multicolumn{4}{|c|}{ Probability (x of n marmots melanistic) } \\
\hline $\begin{array}{c}\text { Paternal } \\
\text { Genotype }\end{array}$ & $\begin{array}{c}\text { Probability } \\
\text { of Paternal } \\
\text { Genotype }\end{array}$ & $x=0$ & $x=1$ & $\cdots$ & $x=n$ \\
\hline MM & $p^{2}$ & 0 & 0 & 0 & 1 \\
\hline$M N$ & $2 p(1-p)$ & $\begin{array}{c}\text { Binomial } \\
(n, 0, y)\end{array}$ & $\begin{array}{c}\text { Binomial } \\
(n, 1, x)\end{array}$ & $\cdots$ & $\begin{array}{c}\text { Binomial } \\
(n, n, y)\end{array}$ \\
\hline$N N$ & $(1-p)^{2}$ & 1 & 0 & 0 & 0 \\
\hline
\end{tabular}

where Binomial $(n, x, 1 / 2)$ represents the binomial probability distribution, given by:

Binomial $\left(n, x, \frac{1}{2}\right)=\left(\begin{array}{l}n \\ x\end{array}\right)\left(\frac{1}{2}\right)^{x}\left(1-\frac{1}{2}\right)^{(n-x)}$ for $x=0,1, \ldots, n$

The probability $1 / 2$ is calculated from the Punnett square,

\begin{tabular}{|c|c|c|}
\hline & \multicolumn{2}{|c|}{ Male Genotype } \\
\hline $\begin{array}{c}\text { Female } \\
\text { Genotype }\end{array}$ & $\mathrm{M}$ & $\mathrm{N}$ \\
\hline $\mathrm{N}$ & $\mathrm{MN}$ & $\mathrm{NN}$ \\
\hline $\mathrm{N}$ & $\mathrm{MN}$ & $\mathrm{NN}$ \\
\hline
\end{tabular}

and represents the probability that a juvenile born from a male with genotype $M N$ and a female with genotype NN will be melanistic (that is, 2 out of 4 , or $1 / 2$, of the recombinations will exhibit melanistic fur color, demonstrated by MN).

Consequently, if $\mathbf{n}$ represents the size of a litter, and $\mathbf{x}$ is the number of observed melanistic babies, then the probability associated with observing $x$ melanistic babies u times out of $v$ total litters of size $\mathbf{n}$ is given by:

$$
\begin{gathered}
(1-p)^{2}+\left(\frac{1}{2}\right)^{n} 2 p(1-p)=\frac{u}{v}, \quad \text { for } x=0 \\
p^{2}+\left(\frac{1}{2}\right)^{n} 2 p(1-p)=\frac{u}{v}, \quad \text { for } x=n \\
\left(\begin{array}{c}
n \\
x
\end{array}\right)\left(\frac{1}{2}\right)^{n} 2 p(1-p)=\frac{u}{v}, \quad \text { for } x \neq n
\end{gathered}
$$

Table 9 (see Appendix A) lists values based on the above formulas for the theoretical conditional probability distribution for number of melanistic juveniles from normal-pelaged mothers assuming that the allele for melanism is dominant. These values will be used later for comparison to data actually observed in the field.

\section{Case 2. Melanism Manifested by a Recessive}

\section{Allele}

Under the assumption that melanism is manifested by a recessive allele at a single locus, and that only 2 alleles are responsible for fur coloration, application of the Hardy Weinberg Law yields:

$$
p=\sqrt{r}=0.4118
$$

where $p$ is the theoretical proportion of genes in the gene pool for melanism, and $r$ is the proportion of observed melanistic marmots.

Analogous to Case 1, two methods are developed for examining the likelihood that melanism is manifested by a recessive allele. However, because melanism results from a recessive allele, and the female is normal-phased, her genotype may be $\mathrm{NN}$ or $\mathrm{MN}$, and the problem becomes more complex. All possible female genotypes must be considered with all possible male genotypes and are illustrated in the diagram below:

\begin{tabular}{|c|c|c|c|c|}
\hline $\begin{array}{c}\text { Female } \\
\text { Genotype }\end{array}$ & $\begin{array}{c}\text { Probability } \\
\text { of Male } \\
\text { Genotype }\end{array}$ & $\begin{array}{c}\text { Male } \\
\text { Genotype }\end{array}$ & $\begin{array}{c}\text { Probability } \\
\text { of Female } \\
\text { Genotype }\end{array}$ & $\begin{array}{c}\text { Proportion } \\
\text { of Observed } \\
\text { Melanistic } \\
\text { Juveniles }\end{array}$ \\
\hline NN & $(1-p)^{2}$ & NN or MN & 1 & 0 \\
\hline$M N$ & $2 p(1-p)$ & NN & $(1-p)^{2}$ & 0 \\
\hline$M N$ & $2 p(1-p)$ & MN & $2 p(1-p)$ & 1 \\
\hline$M N$ & $2 p(1-p)$ & $M$ & $p^{2}$ & $1 /$ \\
\hline
\end{tabular}


If $s$ is the observed proportion of melanistic young from normal-phased females, then $s$ is equal to the conditional probability that a juvenile is melanistic given that the female is normal, and may be calculated by:

$s=\frac{\frac{3}{2}[2 p(1-p)]^{2}+\frac{3}{2}\left[p^{2} 2 p(1-p)\right]}{(1-p)^{2}+2 p(1-p)}=\frac{p^{2}}{1+p}=\frac{r}{1+\sqrt{r}}=0.1201$

From Table 8 (see Appendix A),s is 10/46 $=0.2174$. The relative closeness of 0.2174 to 0.1201 , and the likelihood that melanism is manifested by a recessive allele, are evaluated in the following section.

The second method is more complex and considers all possible maternal and paternal genotypes with consequent juvenile genetic recombinations, illustrated in the diagram below:

\begin{tabular}{|c|c|c|c|c|c|c|c|}
\hline \multirow[b]{2}{*}{$\begin{array}{l}\text { Female } \\
\text { Geno- } \\
\text { type }\end{array}$} & \multirow[b]{2}{*}{$\begin{array}{l}\text { Prob. } \\
\text { Female } \\
\text { Geno. }\end{array}$} & \multirow[b]{2}{*}{$\begin{array}{c}\text { Male } \\
\text { Geno- } \\
\text { type }\end{array}$} & \multirow[b]{2}{*}{$\begin{array}{l}\text { Prob. } \\
\text { Male } \\
\text { Geno. }\end{array}$} & \multicolumn{4}{|c|}{$\begin{array}{l}\text { Probability } \\
\text { ( } x \text { of } n \text { marmots melan.) }\end{array}$} \\
\hline & & & & 0 & 1 & $\ldots$ & $n$ \\
\hline $\mathrm{NN}$ & $(1-p)^{2}$ & ANY & 1 & 1 & 0 & 0 & 0 \\
\hline $\mathrm{MN}$ & $2 p(1-p)$ & $\mathrm{NN}$ & $(1-p)^{2}$ & 1 & 0 & 0 & 0 \\
\hline $\mathbf{M N}$ & $1-p)$ & $\mathbf{M N}$ & $2 p(1-p)$ & $\begin{array}{c}\text { Bino } \\
n, 0,1\end{array}$ & $\begin{array}{c}\text { Bino } \\
\text { n, } 1,1\end{array}$ & $\ldots$ & $\begin{array}{l}\text { Bino } \\
n, n, 1\end{array}$ \\
\hline MN & $2 p(1 \cdot p)$ & $M$ & $p^{2}$ & $\begin{array}{c}\text { Bino } \\
n, 0,4\end{array}$ & $\begin{array}{l}\text { Bino } \\
n, 1, K\end{array}$ & $\ldots$ & $\begin{array}{l}\text { Bino } \\
n, n, y\end{array}$ \\
\hline
\end{tabular}

Analogous to Case 1 , but based on the above diagram, if $\mathrm{n}$ represents the size of a litter, and $x$ is the number of observed melanistic babies, then the probability associated with observing $x$ melanistic babies $u$ times out of $v$ total litters of size $\mathbf{n}$ is given by:

$$
\begin{aligned}
& \frac{(1-p)^{2}+2 p(1-p)^{3}+\left(\frac{3}{4}\right)^{n}[2 p(1-p)]^{2}+\left(\frac{1}{2}\right)^{n}\left[2 p^{3}(1-p)\right]}{1-p^{2}}=\frac{u}{v}, \text { for } x=0 \\
& \frac{\left(\begin{array}{l}
n \\
x
\end{array}\right)\left(\frac{1}{4}\right)^{x}\left(\frac{3}{4}\right)^{(n-x)}[2 p(1-p)]^{2}+\left(\begin{array}{l}
n \\
x
\end{array}\right)\left(\frac{1}{2}\right)^{n}\left[2 p^{3}(1-p)\right]}{1-p^{2}}=\frac{u}{v}, \text { for } x=0
\end{aligned}
$$

Table 10 (see Appendix A) lists values based on the above formulas for the theoretical conditional probability distribution for number of melanistic juveniles from normal-pelaged mothers assuming that the allele for melanism is recessive. These values will be used later for comparison to data actually observed in the field.

\section{COMPARING THE TWO CASES}

Table 11 (see Appendix A) presents the proportion of time $x$ melanistic babies from litters of size $\mathbf{n}$ was observed in the field. This information is given in the same format as Tables 9 and 10 , to facilitate comparison of corresponding values.

Table 12 (see Appendix A) lists the theoretical and observed proportions corresponding to both methods for which data were collected. Although different strategies are currently under development to determine whether the observed data most likely indicate that melanism is caused by a dominant or recessive allele, a distance norm, which is a relative measure of the distance 2 points in multidimensional space lie from each other is used in this report. Matrices defining the 2 cases and the observed data (Tables 9, 10, 11 and Appendix A) are depicted as points in multidimensional space and corresponding distance norms are calculated by summing the squares of the difference of matrix entries for each theoretical case with the observed case, and summarized below:

\begin{tabular}{|c|c|c|}
\hline & \multicolumn{2}{|c|}{ Distance Norm for: } \\
\hline Methods: & $\begin{array}{c}\text { Melanism Allele } \\
\text { Dominant }\end{array}$ & $\begin{array}{c}\text { Melanism Allele } \\
\text { Recessive }\end{array}$ \\
\hline Observed Proportion with: & 1.62383 & 1.16700 \\
\hline Method 1: "s" with: & 0.0166 & 0.0095 \\
\hline
\end{tabular}

The distance norm calculated using values obtained in both methods indicates that the data most likely support that melanism is manifested by a recessive allele, since a smaller distance norm implies closer agreement of categories being compared.

One final approach that merits attention, especially since the data are limited, involves s, the proportion of melanistic juveniles from nonmelanistic mothers, discussed in Method 1. The observed proportion of melanistic juveniles from non-melanistic mothers is $10 / 46=0.2174$. A $95 \%$ confidence interval on $s$ is $(0.09819,0.33659)$. In theory, $s$ for the melanistic case is 0.0887 , and $s$ for the recessive case is 0.1201 . With $95 \%$ confidence, only $\mathbf{s}$ under the recessive assumption falls within this interval. Therefore, the data most likely support that melanism is manifested by a recessive allele.

As stated previously, the significance of this analysis is questionable since additional data from on-going (long-term) studies are required, and other genetic situations (for example, multiple alleles at multiple loci) must be investigated. Michael Crone (1995) has recently completed a 
Master's Thesis that provides a detailed genetic analysis and is available upon request.

\section{ACKNOWLEDGEMENTS}

I wish to extend my deepest gratitude to the University of Wyoming Faculty Grant-in-Aid Program, and to the University of WyomingNational Park Service Research Station, for supporting this project; to Nick Visser, Kim Springer, Hank Harlow, Don Roth, Adrianna Valladares, Michael Crone, Steve Bieber, Richard Anderson-Sprecher, Doug Bonett, Myron Allen, and other University of Wyoming personnel, for their support and technical expertise; to Alan Harmata, for technical expertise; to Steve Cain, Rick Wallen, Mason Reed, Dan Burgette, the Jenny Lake Rescue Rangers, and other Grand Teton National Park personnel, for their participation and collaboration; to Laura Archer, Zach Harlow, Siri Ibarguan, Hal Janson, Helen Larson, and Heather McDonald, for volunteering their time in the field; to Delia Montopoli, and Michelle Montopoli, for support and assistance in trapping marmots.

\section{$\downarrow \quad$ Literature Cited}

Armitage, K. B. 1961. Frequency of melanism in the golden-mantled marmot. J. Mammal. 42:100-101.

, 1962. Social behavior of a colony of yellow-bellied marmots Marmota flaviventris. Anim. Behav. 10:319-331.

1974. Male behavior and territoriality in the yellow-bellied marmot. J. Zool. 172:233265.

1982. Marmots and coyotes: Behavior of prey and predator. J. Mamm. 63(3):503505 .

Burt, W.H. and Grossenheider, R.P. 1976. A field guide to the mammals of America north of Mexico (3rd ed.). Houghton Mifflin Company, Boston.
Clarke, C. A., and P.M. Sheppard. 1966. A local survey of the distribution of industrial melanic forms in the moth Biston bistularia and estimates of the selective values of these in an industrial environment. Proc. R. Soc. Lond. (Biol.) 165:424-439.

Craighead, F. C. Jr. 1951. A biological and economic evaluation of coyote predation. New York Zool. Soc. 23 pp.

Crone, M. 1995. A technique for determining the genetic structure of a phenotype and its application to the study of melanism in the marmots of the Teton Range in Wyoming. Master's Thesis, University of Wyoming, Laramie.

Downhower, J. F. and Armitage, K. E. 1981. Dispersal of yearling yellow-bellied marmots Marmota flaviventris. Animal Behavior, 29, 1064-1069.

Fryxell, F. M. 1928. Melanism among the marmots of the Teton Range, Wyoming. J. Mammal. 9:336-337.

Garrott, R.A. and D.A. Jeni. 1978. Arboreal behavior of yellow-bellied marmots. J. Mammal. 59(2):433-434.

Kettlewell, H. B. D. 1961. The phenomenon of industrial melanism in the Lepidoptera. Ann. Rev. Emtomol. 6:245-262.

Kilgore, D. L. Jr. 1972. Energy dynamics of the yellow-bellied marmot Marmota flaviventris: A hibernator。 Ph.D. Thesis, The University of Kansas, Lawrence. 82pp.

Kiltie, R. A. 1989. Wildfire and the evolution of dorsal melanism in fox squirrels, Sciurus niger. J. Mammal. 70(4):726-739.

Murie, O. J. 1934. Melanism in an Alaskan vole. J. Mammal. 15:323.

Swarth, H.S. 1912. Univ. of California Publ. Zool., X, 89-90. 
Travis, S. E. and Armitage, K. E. 1972. Some quantitative aspects of the behavior of marmots. Trans. Kan. Acad. Sci. 75(4):308-321.

Walsberg, G. E., Campbell, G. S., and King, J. R. 1978. Animal coat color and radiative heat gain: A re-evaluation. Jour. Comp. Physiol. 126:211-222.
Woodward, J.A., Bonett, D.G., and Brecht, M. 1990. Introduction to linear models and experimental design. Harcourt Brace Jovanovich Publishers, Academic Press, Austin. 


\title{
APPENDIX A
}

\author{
FIGURES AND TABLES
}

\section{LIST OF FIGURES AND TABLES}

Table 1. Incidence of Pelage Color by Survey Areas $\ldots \ldots \ldots \ldots \ldots \ldots \ldots \ldots \ldots \ldots \ldots$

Table 2. Backcountry Use Information from Trail Counters $\ldots \ldots \ldots \ldots \ldots \ldots \ldots \ldots \ldots$

Table 3. Relative Human Concentration in Backcountry Areas $\ldots \ldots \ldots \ldots \ldots \ldots \ldots \ldots \ldots \ldots$

Table 4. Proportion of Melanistic Marmots Versus Human Use . . . . . . . . . . . . . . . 24

Table 5. Proportion of Melanistic Marmots Versus Backcountry Use . . . . . . . . . . . . 25

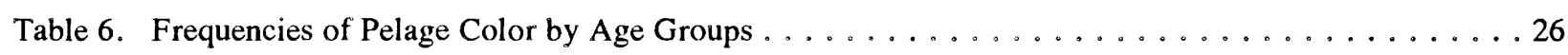

Table 7. Tests of All Pairwise Differences of Proportions $\ldots \ldots \ldots \ldots \ldots \ldots \ldots \ldots$

Table 8. Litter Sizes and Number of Melanistic Marmots by Location . . . . . . . . . . . . 27

Table 9. Theoretical Probability Distribution for Number of Melanistic Juveniles from Normal-Pelaged Mothers Assuming Allele for Melanism is Dominant . . . . . . . . . . . . . . . . 28

Table 10. Theoretical Probability Distribution for Number of Melanistic Juveniles from Normal-Pelaged Mothers Assuming Allele for Melanism is Recessive . . . . . . . . . . . . . . . . 28

Table 11. The Proportion of Time x Melanistic Juveniles from Litters of Size $n$ Was Observed in the Field . . . . . . . . . . . . . . . 28

Table 12. Common Proportions Used for Comparing Different Likelihood Criteria using Both Methods 
Table 2. Incidence of Pelage Color by Survey Areas

\begin{tabular}{|c|c|c|c|}
\hline $\begin{array}{l}\text { Location } \\
\text { (n=number of surveys) }\end{array}$ & $\begin{array}{l}\text { Number of } \\
\text { Melanistic }\end{array}$ & $\begin{array}{l}\text { Number of } \\
\text { Normal }\end{array}$ & $\begin{array}{l}\text { Number } \\
\text { of Other }\end{array}$ \\
\hline Alaska Basin $(n=2)$ & 4 & 11 & 2 \\
\hline Avalanche Canyon $(n=1)$ & 0 & 2 & 0 \\
\hline $\begin{array}{l}\text { Cascade Canyon: } \\
\text { Jenny Lake co Forks }(n=5) \\
\text { Forks to Solitude Lake }(n=6) \\
\text { Sol itude Lake Area }(n=4) \\
\text { Forks to Hurricane Pass }(n=4)\end{array}$ & $\begin{array}{l}2 \\
6 \\
4 \\
1 \\
\end{array}$ & $\begin{array}{l}12 \\
63 \\
10 \\
23 \\
\end{array}$ & $\begin{array}{l}0 \\
6 \\
2 \\
4\end{array}$ \\
\hline $\begin{array}{l}\text { Deach Canyon: } \\
\text { Phelps Laxe to Cabin }(n=2) \\
\text { Cabin co Fox Creek Pass }(n=1) \\
\text { Deach Shelf }(n=4)\end{array}$ & $\begin{array}{l}3 \\
1 \\
0\end{array}$ & $\begin{array}{c}8 \\
2 \\
23 \\
\end{array}$ & $\begin{array}{l}0 \\
0 \\
5\end{array}$ \\
\hline $\begin{array}{l}\text { Garnet Canyon: } \\
\text { rrail to Garnet Junction (n=5) } \\
\text { Meadows Area }(n=1) \\
\text { Lower Saddle Area }(n=4) \\
\text { South Fork Area }(n=3) \\
\text { Above Lower Saddle/Grand }(n=1)\end{array}$ & $\begin{array}{l}6 \\
0 \\
2 \\
0 \\
2\end{array}$ & $\begin{array}{c}7 \\
6 \\
33 \\
9 \\
0\end{array}$ & $\begin{array}{l}0 \\
2 \\
3 \\
5 \\
0\end{array}$ \\
\hline $\begin{array}{l}\text { Granite Canyon: } \\
\text { Tram through S/M Forks }(n-1)\end{array}$ & $\underline{0}$ & 3 & 0 \\
\hline $\begin{array}{l}\text { Hanging Canyon: } \\
\text { Trail to Arrowhead Lake }(n=4) \\
\text { Arrowhead to Lake Crags }(n=3) \\
\text { Laurel Lake }(n=1)\end{array}$ & $\begin{array}{l}5 \\
2 \\
0 \\
\end{array}$ & $\begin{array}{c}12 \\
7 \\
1 \\
\end{array}$ & $\begin{array}{l}0 \\
5 \\
0 \\
\end{array}$ \\
\hline $\begin{array}{l}\text { Housing Areas: } \\
\text { Beaver Creek Boneyard }(n=2) \\
\text { Climber's Ranch }(n=3) \\
\text { Highland's Houging Area }(n=2)\end{array}$ & $\begin{array}{l}1 \\
2 \\
6 \\
\end{array}$ & $\begin{array}{l}4 \\
6 \\
6 \\
\end{array}$ & $\begin{array}{l}0 \\
0 \\
0 \\
\end{array}$ \\
\hline $\begin{array}{c}\text { Isolaced Lake Areas: } \\
\text { Delca Lake }(n=1) \\
\text { Grizzly Bear Lake }(n=1) \\
\text { Marion Lake }(n=4) \\
\text { Moose Ponds }(n=1) \\
\text { Surprise/Amphitheacer }(n=4)\end{array}$ & $\begin{array}{c}1 \\
0 \\
13 \\
0 \\
1 \\
1\end{array}$ & $\begin{array}{c}1 \\
2 \\
12 \\
3 \\
7\end{array}$ & $\begin{array}{l}0 \\
1 \\
2 \\
0 \\
5\end{array}$ \\
\hline $\begin{array}{l}\text { Paintbrush Canyon: } \\
\text { Trail co Holly Lake }(n=2) \\
\text { Molly Lake Area }(n=3) \\
\text { Holly Lake to Divide }(n=5)\end{array}$ & $\begin{array}{l}0 \\
3 \\
4\end{array}$ & $\begin{array}{l}10 \\
14 \\
12 \\
\end{array}$ & $\begin{array}{c}1 \\
6 \\
10\end{array}$ \\
\hline $\begin{array}{c}\text { Taggart Lake 3urn Area: } \\
\text { Corral to Taggare Lake }(n=5)\end{array}$ & 1 & 15 & 0 \\
\hline
\end{tabular}

Table 2. Backcountry Use Information from Trail Counters

\begin{tabular}{|c|c|}
\hline Location & $\begin{array}{c}\text { Average } \\
\text { Number of People } \\
\text { per Day }\end{array}$ \\
\hline Avalanche Canyon: & $6.1^{1}$ \\
\hline $\begin{array}{c}\text { Cascade Canyon: } \\
\text { Boat Traffic } \\
\text { Jenny Lake, S.W. Shore } \\
\text { String Lake, South }\end{array}$ & $\begin{array}{c}905.7^{2} \\
385.8\end{array}$ \\
231.3
\end{tabular}

1 Estimated from 1993 data only (1994 data not available)

2 Estimated from 1993 data only (1994 data not available)

3 Estimated from 1994 data only (1993 data not available)

Table 3. Relative Human Concentration in Backcountry Areas

\begin{tabular}{|c|c|}
\hline Location & $\begin{array}{c}\text { Average } \\
\text { Score }\end{array}$ \\
\hline Avalanche Canyon & 2.54 \\
\hline $\begin{array}{l}\text { Cascade Canyon: } \\
\text { Jenny Lake to Inspiration Point } \\
\text { Inspiration Point to Forks } \\
\text { Forks to Solitude Lake } \\
\text { Forks to Hurricane Pass } \\
\end{array}$ & $\begin{array}{l}10 \\
8.23 \\
6.85 \\
5.46 \\
\end{array}$ \\
\hline $\begin{array}{l}\text { Death Canyon: } \\
\text { Lower and Upper Canyon } \\
\text { Death Shelf } \\
\end{array}$ & $\begin{array}{l}5.46 \\
4.54 \\
\end{array}$ \\
\hline $\begin{array}{l}\text { Garnet Canyon: } \\
\text { Platforms/Meadows } \\
\text { Caves } \\
\text { Lower Saddle } \\
\text { South Fork }\end{array}$ & $\begin{array}{l}7.77 \\
7.46 \\
7.58 \\
5.62 \\
\end{array}$ \\
\hline $\begin{array}{l}\text { Granite Canyon: } \\
\text { North Fork } \\
\text { South/Middle Forks }\end{array}$ & $\begin{array}{l}4.77 \\
4.54 \\
\end{array}$ \\
\hline Hanging Canyon & 4 \\
\hline $\begin{array}{c}\text { Isolated Lakes: } \\
\text { Grizzly Bear Lake } \\
\text { Marion Lake } \\
\text { Surprise/Amphitheater Lakes }\end{array}$ & $\begin{array}{l}1.92 \\
5.62 \\
7.46 \\
\end{array}$ \\
\hline $\begin{array}{l}\text { Paintbrush Canyon: } \\
\text { Lower Paintbrush } \\
\text { Holly Lake } \\
\text { Upper Paintbrush }\end{array}$ & $\begin{array}{l}5.77 \\
5.85 \\
4.54\end{array}$ \\
\hline $\begin{array}{l}\text { String/Leigh Lake Area: } \\
\text { String Lake to Trapper Lake } \\
\text { Leigh Lake to CMC Camp (Moran) }\end{array}$ & $\begin{array}{l}7.42 \\
2.67 \\
\end{array}$ \\
\hline
\end{tabular}

Table 4. Proportion of Melanistic Marmots Versus Human Use Score

\begin{tabular}{|c|c|c|}
\hline Location & $\begin{array}{l}\text { Proportion } \\
\text { of } \\
\text { Melanistic } \\
\text { Mamots }\end{array}$ & $\begin{array}{l}\text { Human } \\
\text { Use } \\
\text { Score }\end{array}$ \\
\hline Avalanche Canyon: & 0.0 & 2.54 \\
\hline $\begin{array}{l}\text { Cascade Canyon: } \\
\text { Jenny Lake to Forks } \\
\text { Forks to Solitude Lake } \\
\text { Forks to Hurricane Pass }\end{array}$ & $\begin{array}{l}0.143 \\
0.110 \\
0.036\end{array}$ & $\begin{array}{l}9.12 \\
6.85 \\
5.46\end{array}$ \\
\hline $\begin{array}{l}\text { Death Canyon: } \\
\text { Lower and Upper Canyon } \\
\text { Death Shelf }\end{array}$ & $\begin{array}{c}0.286 \\
0.0\end{array}$ & $\begin{array}{l}5.46 \\
4.54\end{array}$ \\
\hline $\begin{array}{c}\text { Garnet Canyon: } \\
\text { Platforms/Meadows/Caves } \\
\text { Lower Saddle } \\
\text { South Fork }\end{array}$ & $\begin{array}{l}0.0 \\
0.053 \\
0.0\end{array}$ & $\begin{array}{l}7.62 \\
7.58 \\
5.62 \\
\end{array}$ \\
\hline Granite Canyon: & 0.0 & 4.66 \\
\hline Hanging Canyon: & 0.226 & 4.0 \\
\hline $\begin{array}{c}\text { Isolated Lakes: } \\
\text { Grizzly Bear Lake } \\
\text { Marion Lake } \\
\text { Surprise/Amphitheater Lk }\end{array}$ & $\begin{array}{l}0.0 \\
0.481 \\
0.077\end{array}$ & $\begin{array}{l}1.92 \\
5.62 \\
7.46 \\
\end{array}$ \\
\hline $\begin{array}{c}\text { Paintbrush Canyon: } \\
\text { Lower Paintbrush } \\
\text { Holly Lake } \\
\text { Upper Paintbrush }\end{array}$ & $\begin{array}{l}0.0 \\
0.130 \\
0.154 \\
\end{array}$ & $\begin{array}{l}5.77 \\
5.85 \\
4.54 \\
\end{array}$ \\
\hline
\end{tabular}


Table 5. Proportion of Melanistic Marmots Versus Backcountry Use

\begin{tabular}{|c|c|c|}
\hline Location & $\begin{array}{c}\text { Proportion } \\
\text { of } \\
\text { Melanistic } \\
\text { Marmots }\end{array}$ & $\begin{array}{c}\text { Average } \\
\text { Number } \\
\text { People } \\
\text { per Day }\end{array}$ \\
\hline Avalanche Canyon: & 0.0 & 6.1 \\
\hline $\begin{array}{c}\text { Cascade Canyon': } \\
\text { Jenny Lk to Forks } \\
\text { Forks to Solitude Lk }\end{array}$ & 0.143 & $\begin{array}{c}341.5 \\
142.3\end{array}$ \\
\hline Death Canyon: & 0.095 & 175.9 \\
\hline Garnet Canyon: & 0.065 & 61.6 \\
\hline Granite Canyon: & 0.0 & 101.5 \\
\hline Hanging Canyon: & 0.226 & 18.7 \\
\hline Surprise/Amphitheater Lk & 0.077 & 110.7 \\
\hline Taggart Lake Burn Area & 0.063 & 170.8 \\
\hline
\end{tabular}

Table 6. Frequencies of Pelage Color by Age Groups

1 Values for Number of People per Day are estimated from information provided by GTNP Ranger D. Burgette (pers. comments, 1995), in a study of backcountry trends

\begin{tabular}{|c|c|c|c|c|}
\hline Pelage TYpe & Juveniles & $\begin{array}{c}\text { Yearlings/ } \\
\text { Subadules }\end{array}$ & Adulcs & Toral \\
\hline Normal & $\begin{array}{c}67 \\
(0.591)\end{array}$ & $\begin{array}{c}86 \\
(0.585)\end{array}$ & $\begin{array}{c}171 \\
(0.822)\end{array}$ & 327 \\
\hline Melanistic & $\begin{array}{c}15 \\
(0.155)\end{array}$ & $\begin{array}{c}39 \\
(0.265)\end{array}$ & $\begin{array}{c}16 \\
(0.077)\end{array}$ & 70 \\
\hline Orher & $\begin{array}{c}25 \\
(0.155)\end{array}$ & $\begin{array}{c}22 \\
(0.150)\end{array}$ & $(0.101)$ & 58 \\
\hline Total & 97 & 147 & 208 & 452 \\
\hline
\end{tabular}

Table 9. Liccer Sizes and Number of Melanistic Marmots by
Location

Table 7. Tests of All pairwise Differences of Proportions

\begin{tabular}{|c|c|c|c|}
\hline Fur coloration & $\begin{array}{c}\text { Compared } \\
\text { Age Categories }\end{array}$ & $z$-value & p-value \\
\hline \multirow{3}{*}{ Normal } & $\begin{array}{c}\text { Juvenile with } \\
\text { Yearling/Subadulc }\end{array}$ & 1.67 & 0.0950 \\
\hline & $\begin{array}{c}\text { Yearling/Subadult } \\
\text { with Adult }\end{array}$ & .4 .92 & 0.0000 \\
\hline & $\begin{array}{l}\text { Juvenile with } \\
\text { Adult }\end{array}$ & -2.58 & 0.0098 \\
\hline \multirow{3}{*}{ Meianistic } & $\begin{array}{c}\text { Juvenile with } \\
\text { Yearling/Subadule }\end{array}$ & -2.04 & 0.0416 \\
\hline & $\begin{array}{c}\text { Yearling/Subadult } \\
\text { with Adult }\end{array}$ & 4.83 & 0.0000 \\
\hline & $\begin{array}{l}\text { Juvenile with } \\
\text { Adult }\end{array}$ & 2.10 & 0.0364 \\
\hline \multirow{3}{*}{ Ocher } & $\begin{array}{l}\text { Juvenile with } \\
\text { Yearling/Subadult }\end{array}$ & 0.11 & 0.9156 \\
\hline & $\begin{array}{c}\text { Yearling/Subadult } \\
\text { with Adult }\end{array}$ & 1.39 & 0.1646 \\
\hline & $\begin{array}{l}\text { Juvenile with } \\
\text { Adult }\end{array}$ & 1.35 & 0.1770 \\
\hline
\end{tabular}

\begin{tabular}{|c|c|c|}
\hline Locacion & Litter Size & $\begin{array}{c}\text { Number of } \\
\text { Melaniseic } \\
\text { Marmoes }\end{array}$ \\
\hline Alaska Basin: & $\begin{array}{l}3 \\
2 \\
\end{array}$ & $\begin{array}{l}2 \\
0 \\
\end{array}$ \\
\hline $\begin{array}{l}\text { Cascade Canyon: } \\
\text { Jenny Lake to Forks } \\
\text { Forks to Solitude Lake } \\
\text { Forks to Hurricane Pass }\end{array}$ & $\begin{array}{l}2 \\
1 \\
2 \\
2 \\
1 \\
4 \\
\end{array}$ & $\begin{array}{l}0 \\
0 \\
0 \\
0 \\
0 \\
0 \\
\end{array}$ \\
\hline Deacin Canyon (Lower): & 1 & 0 \\
\hline Garnes Canyon (Meadows): & 1 & 0 \\
\hline Hanging Canyon (Lower): & $\begin{array}{l}2 \\
2 \\
3 \\
\end{array}$ & $\begin{array}{l}0 \\
2 \\
1 \\
\end{array}$ \\
\hline $\begin{array}{l}\text { Housing Areas: } \\
\text { Beaver Creek Boneyard } \\
\text { Highland's Housing Area } \\
\end{array}$ & $\begin{array}{l}3 \\
4 \\
\end{array}$ & $\begin{array}{l}1 \\
2 \\
\end{array}$ \\
\hline Marion Lake & $\begin{array}{l}4 \\
2 \\
\end{array}$ & $\begin{array}{l}1 \\
1 \\
\end{array}$ \\
\hline $\begin{array}{c}\text { Paintbrush Canyon: } \\
\text { Lowez Paintbrush } \\
\text { Holly Lake } \\
\text { Upper Paintbrush } \\
\end{array}$ & $\begin{array}{l}1 \\
2 \\
1 \\
1 \\
\end{array}$ & $\begin{array}{l}0 \\
0 \\
0 \\
0 \\
\end{array}$ \\
\hline Taggart Lake Burn Area: & $\begin{array}{l}1 \\
1 \\
\end{array}$ & $\begin{array}{l}0 \\
0 \\
\end{array}$ \\
\hline
\end{tabular}


Table 9. Theoretical Probability Distribution for Number of Melanistic Juveniles from Normal-Pelaged Mothers Assuming Allele for Melanism is Dominant

\begin{tabular}{||c|c|c|c|c|c|}
\hline & \multicolumn{5}{|c|}{ Number of Melanistic Juveniles } \\
\hline $\begin{array}{c}\text { Litter } \\
\text { Size }\end{array}$ & 0 & 1 & 2 & 3 & 4 \\
\hline 1 & .91129 & .08871 & - & - & - \\
\hline 2 & .87087 & .08084 & .04829 & - & - \\
\hline 3 & .85066 & .06063 & .06063 & .02808 & - \\
\hline 4 & .84056 & .04042 & .06063 & .04042 & .01797 \\
\hline
\end{tabular}

Table 10. Theoretical Probability Distribution for Number of Melanistic Juveniles from Normal-Pelaged Mothers Assuming Allele for Melanism is Recessive

\begin{tabular}{|c|c|c|c|c|c|}
\hline & \multicolumn{5}{|c|}{ Number of Melanistic Juveniles } \\
\hline $\begin{array}{c}\text { Litter } \\
\text { Size }\end{array}$ & 0 & 1 & 2 & 3 & 4 \\
\hline 1 & .87990 & .12010 & - & - & - \\
\hline 2 & .80219 & .15542 & .04239 & - & - \\
\hline 3 & .75009 & .15630 & .07683 & .01678 & - \\
\hline 4 & .71411 & .14394 & .09670 & .03797 & .00729 \\
\hline
\end{tabular}

Table 11. The Proportion of Time $x$ Melanistic Juveniles from Litters of Size $n$ Was Observed in the Field

\begin{tabular}{|c|c|c|c|c|c|}
\hline & \multicolumn{5}{|c|}{ Number of Melanistic Juveniles } \\
\hline $\begin{array}{c}\text { Litter } \\
\text { Size }\end{array}$ & 0 & 1 & 2 & 3 & 4 \\
\hline 1 & 1.0 & 0 & - & - & - \\
\hline 2 & 0.750 & 0.125 & 0.125 & - & - \\
\hline 3 & 0 & 0.667 & 0.333 & 0 & - \\
\hline 4 & 0.333 & 0.333 & 0.333 & 0 & 0 \\
\hline
\end{tabular}

Table 12. Common Proportions Used for Comparing Different

\begin{tabular}{|c|c|c|c|}
\hline \multirow{2}{*}{$\begin{array}{l}\text { Merhod 2: } \\
\text { (Number in } \\
\text { Lieter. } \\
\text { Number } \\
\text { Melaniscic) }\end{array}$} & \multirow[b]{2}{*}{$\begin{array}{l}\text { Observed } \\
\text { proportion }\end{array}$} & \multicolumn{2}{|c|}{ Theoretical Proportions Assuming: } \\
\hline & & $\begin{array}{c}\text { Melanism Allele } \\
\text { Dominant }\end{array}$ & $\begin{array}{c}\text { Melanism Allele } \\
\text { Recessive }\end{array}$ \\
\hline$(1,0)$ & 1.0 & 0.91129 & 0.87990 \\
\hline$(1,1)$ & 0 & 0.08871 & 0.12010 \\
\hline$(2,0)$ & 0.7500 & 0.87087 & 0.80219 \\
\hline$(2,1)$ & 0.1250 & 0.08084 & 0.15542 \\
\hline$(2,2)$ & 0.1250 & 0.04829 & 0.04239 \\
\hline$(3,0)$ & 0 & 0.85066 & 0.75009 \\
\hline$(3,1)$ & 0.6667 & 0.06063 & 0.15630 \\
\hline$(3,2)$ & 0.3333 & 0.06063 & 0.07683 \\
\hline$(3,3)$ & 0 & 0.02808 & 0.01678 \\
\hline$(4,0)$ & 0.3333 & 0.84056 & 0.71411 \\
\hline$(4,1)$ & 0.3333 & 0.04042 & 0.14394 \\
\hline$(4,2)$ & 0.3333 & 0.06063 & 0.09670 \\
\hline$(4,3)$ & 0 & 0.04042 & 0.03797 \\
\hline$(4,4)$ & 0 & 0.01797 & 0.00729 \\
\hline \multicolumn{4}{|l|}{ Merhod 1: } \\
\hline $\mathbf{s}$ & 0.1736 & 0.0887 & 0.1201 \\
\hline
\end{tabular}




\section{APPENDIX B}

\section{OTHER INTERESTING OBSERVATIONS THAT MERIT INVESTIGATION}

During the previous summers, several interesting observations that merit investigation were encountered.

1. Marmots have been encountered at very high altitudes, often near summits of peaks:

- during a climb of Teewinot, at an altitude of ca. $3650 \mathrm{~m}(12,000 ')$, summer, 1994.

- on the East Ridge of the Grand Teton, ca. 3560m (11,700'), summer, 1994.

- on the East Face of the Grand Teton, ca. $3650 \mathrm{~m}\left(12,000^{\prime}\right.$,), on extremely technical ground, summer, 1991.

- on the CMC route of Mount Moran, summer, 1994.

- Fryxell (1928) wrote: "in August, 1926, ... I caught a fleeting glimpse of a small black animal, below the second saddle of the peak (Grand), at an altitude of $12,500 \mathrm{ft}$, " which he later believed was a melanistic marmot. K. Springer (field assistant), in 1994, described in her field notes a melanistic marmot at approximately the same location.

2. Two extremely impressive burrows were encountered by G. Montopoli:

- in June, 1993, a 10-15m tunnel emerging out of a snow field that was nearly ice, Garnet Canyon Meadows.

- during summer, 1994, above Marion Lake, a 20x20cm rectangular "tunnel" (probably a burrow), carved into rock on a vertical rock face approximately $1.5 \mathrm{~m}$ from the ground, and disappearing into the rock after several meters.

3. In 1994, N. Visser and G. Montopoli both documented at different times and locations marmots "pressed" to dark rocks in a sunning position well after direct sunlight had left the rocks' surface. Examination of the dark rocks indicated warmer temperatures than the surrounding air temperature. In 1995, Visser observed marmots "pressed" to cool rocks in the shade during hot, sunny days.

4. "Kissing" and "paw play" by juveniles were observed by two different field assistants at different times and locations, summer, 1994.

5. In many survey areas there appeared to be common pelage types. For example, the Death Canyon Shelf had a large proportion of light-brown marmots, and Lake Solitude and Marion Lake had a large proportion of black marmots. Pelage type often appeared to be a local phenomenon, indicating that breeding groups may have been somewhat localized (or colonial), and selective in their habitat preferences.

6. The Taggart Lake burn area was investigated for elevated numbers of black marmots. Several studies of sciurids (Kiltie 1989) and other small mammals have indicated differential survival of melanistic individuals in burn areas, probably due to the crypticity of melanistic individuals in dark, charred habitat. The proportion of melanistic marmots in this area was only 0.0625 , well-below the overall population proportion of 0.1549 . Marmots may thus utilize other habitat selection criteria.

7. Pelage coloration for all surveyed populations in the Teton Range (1994) were distributed as: -normal: $71.68 \%$

-melanistic: $15.49 \%$

-other: $12.83 \%$ Armitage, in 1959, found that about one-fourth of the marmots he surveyed in a brief study were melanistic. Comparing his results with the present results, the proportion of melanistic individuals in the population may experience temporal fluctuations. 
8. Several surveys in very remote areas of Grand Teton National Park during previous summers have produced few marmot sightings:

1) surveys of over $160 \mathrm{~km}$ of mountainous terrain west of Jackson Lake to the Continental Divide, over a 9day period during 3 summers, have never documented a melanistic marmot, and the backcountry rangers that patrol that sparsely-used area of the park have reported one sighting during the past 3 summers (Montopoli, pers. obs.);

2) In 1994, Avalanche Canyon was surveyed for an entire day and resulted in 2 marmot sightings (Visser, pers. obs.); and

3) In 1994, an off-trail hike of approximately $12 \mathrm{~km}$ (from Fox Creek Pass, northeast to Forget-Me-Not Lakes along a large shelf, east to Rimrock Lake, and north to Death Canyon trail) produced one marmot sighting (Montopoli, pers. obs.).

9. In 1995, the last marmot sighting occurred September 7th in Cascade Canyon. No other marmots were observed after that date, even though subsequent surveys were made (K. Springer, pers. obs.). In 1995, the last 2 marmots were observed in Garnet Canyon (Gary Wise, pers. communication). Due to heavy snowfall season, Garnet Canyon was snow bound much later than in 1994.

10. In 1995, abundant winter snowfall at higher elevations suggested that marmots migrated substantial distances over snow to lower elevations where food was more available. As the snow melted and food became abundant, the marmots appeared to once again move up to higher altitudes. This unique survival strategy has never been reported before, and was not believed to be possible prior to these observations. In 1996 (again, a particularly heavy snowfall year), a documentation of seasonal migratory patterns by tracking the movement of telemetered marmots will be attempted.

11. Garrott and Jenni (1972) discuss arboreal behavior of two colonies of yellow-bellied marmots that lived in proximity to flood plains of the Bitteroot River. They noted that there are no other records of marmots making regular use of trees. In GTNP, marmots also (occasionally) use trees:

- in 1994/95, an adult melanistic marmot was observed frequently on a branch of a cottonwood tree ( $1 \mathrm{~m}$ in width, dhb) $30 \mathrm{~m}$ above the ground (pers. observations, Montopoli \& Visser; pers. comments, several residents).

- in 1995, a marmot at the valley trail junction of the Garnet Canyon trail, took up residence in a hollowed, erect evergreen tree (pers. observations, Visser \& Montopoli).

- in 1995, a family of marmots ( 2 adults, 3 juveniles) was observed on a branch of a dead snag approximately $5 \mathrm{~m}$ above the ground on the first switchback of the Garnet Canyon trail (pers. comments, D. Carmen, Exum guide).

12. Marmots appear to receive protection from humans against non-habituated predators:

- in 1992, L. Larson (GTNP Climbing Ranger) documented a pine marten/marmot interaction at the Garnet Canyon Petzoldt caves, where the marmot survived only by "joining" a group of humans at the watering hole.

- in 1995, G. Montopoli with the backcountry trail rehabilitation crew observed a golden eagle in a "tucked dive" approaching a melanistic marmot standing erect on a white rock on the lower Garnet Canyon trail. The eagle broke off its attack approximately $10 \mathrm{~m}$ above the marmot when it noticed unintentional movement by the group of people (noted by its eye contact).

- a substantial population of marmots at the Lupine Meadows housing area was decimated when a pair of martens that produced 2 young also took up residence in the housing area (in the loft of the climbing cache). Thus, habituated predators also may enjoy the proximity of humans. 